\title{
Pemanfaatan Saluran Irigasi Sebagai Pembangkit Listrik Tenaga Air (Vortex) untuk Daerah Tidak Terdampak Pasokan Listrik PLN
}

Muhammad Hasan Basri ${ }^{1}$, Rahmat Rizky², Alfin Febrianto ${ }^{3}$, Annasrullah ${ }^{4}$, Aminuddin ${ }^{5}$, As'Aad Bayu Ramadhan ${ }^{6}$, Ahmad Albar Ramadhan7, Yoga Kiani Awk ${ }^{8}$, M.Badrus Zaman ${ }^{9}$, M.Alvin Aris $V^{10}$, Anwar Zamani ${ }^{11}$, Burhanudddin ${ }^{12}$

Universitas Nurul Jadid, Probolinggo 1, 2, 3, 4, 5, 6, 7, 8, 9, 10, 11, 12

\{hasanmohammadbasri83@gmail.com¹, rizkyugik19@gmail.com²,

alfinfebrianto9@gmail.com ${ }^{3}$, anasbaebo2000@gmail.com ${ }^{4}$, audinherex12@gmail.com ${ }^{5}$, bayukece150@gmail.com ${ }^{6}$, albarramadan196@gmail.com7, yogakiani45973@gmail.com, mbadruszaman642@gmail.com ${ }^{9}$, alvinarisahmad@gmail.com ${ }^{10}$, anwarzamani1809@gmail.com ${ }^{11}$, burhanwilliam80@gmail.com $\left.{ }^{12}\right\}$

Submission: 2021-01-31 Received: 2021-04-23 Published: 2021-04-30

Keywords: $\quad$ Abstract. Duren village, ivory sub-district, located in the mountainous Vortex, area south of Probolinggo Regency, is one of the mountainous Mikrohidro, villages that has limited electricity supply or has not yet received Irrigation canals, electricity supply from PLN. Because they have not yet received electricity supply from PLN, the local community uses the irrigation channel as a vortex power plant. Where the area of Duren village is very possible to make a vortex power plant because the irrigation canal is very suitable as a manufacturing location. With the existence of a whirlpool (vortex) power plant, it can alleviate the community of Duren village due to the electricity needs that have not received electricity supply from PLN. Results obtained from channel utilization activities a whirlpool (Vortex) irrigation power plant in the village of Duren arelncreased public knowledge about Vortex Before installing the equipment, first hold a meeting with community leaders in Duren village to determine the important places or facilities to install the equipment. At the installation location and an explanation of the Vortex to the responsible citizen. Instructions are also given directly to those who are given the task of operating the equipment on a daily basis at the time of installation. From this activity it is known that the community does not know how to properly care for and maintain the whirlpool power plant facilities. The material presented was about the basic principles of Vortex and continued with installation and maintenance procedures.

Katakunci:

Vortex, Mikrohidro, Saluran irigasi,
Abstrak. Desa duren kecamatan gading terletak di daerah pegunungan sebelah selatan Kabupaten Probolinggo merupakan salah satu desa pegunungan yang memiliki pasokan listrik terbatas 
atau belom mendapatkan pasokan listrik dari PLN. Karena belum mendapatkan pasokan listrik dari PLN masyarakat setempat memanfaatkan saluran irigasi sebagai pembangkit listrik tenaga pusaran air (vortex). Dimana daerah desa duren tersebut sangat memungkinkan untuk membuat pembagkit listrik tenaga pusaran air (vortex) dikarenakan saluran irigasi sangat layak untuk dijadikan lokasi pembuatan. Dengan adanya pembangkit listrik tenaga pusaran air (vortex) dapat meringankan masyarakat desa duren tekait kebutuhan listrik yang belum mendapatkan pasokan listrik dari PLN.Hasil yang diperoleh dari kegiatan pemanfaatan saluran irigasi pembangkit listrik tenaga pusaran air (Vortex) di desa Duren adalah Peningkatan pengetahuan masyarakat tentang Vortex Sebelum melakukan pemasangan peralatan terlebih dahulu mengadakan pertemuan dengan tokoh masyarakat di desa Duren untuk menentukan tempat atau sarana penting yang akan dipasang peralatan. Pada lokasi pemasangan dan penjelasan tentang Vortex terhadap warga penanggung jawab. Pengarahan juga diberikan secaralangsungkepada pihak yang diberi tugas untuk mengoperasikan peralatan tersebut sehari-hari pada saat pemasangan. Dari kegiatan ini diketahui bahwa masyarakat belum mengetahui bagaimana merawat dan menjaga fasilitas Pembangkit listrik tenaga pusaran air yang benar. Materi yang disampaikan adalah tentang prinsip dasar Vortex dan dilanjutkan dengan tata cara instalasi dan perawatan.

\section{Pendahuluan}

Listrik sampai saat ini sudah menjadi kebutuhan yang cukup penting, tetapi belum semua wilayah Desa Duren mendapatkan aliran listrik PLN karena terjangkau. Bermacam cara dapat digunakan untuk menghasilkan sumber daya listrik seperti menggunakan bahan bakar minyak, pembangkit listrik tenaga matahari, dan pembangkit listrik tenaga air. Seiring dengan kondisi Desa Duren yang sumber utamanya yaitu saluran irigasi yang sangat berguna untuk membuat pembangkit listrik tenaga microhidra dan pembangkit listrik tenaga pusaran air (vortex) (Nafi dkk, 2020).

Pembangkit listrik tenaga pusaran air salah satu yang cocok untuk mendapatkan energi listrik tenaga pusaran air. Desa Duren sampai saat ini ada sebagian wilayah yang belum teraliri aliran listrik dari PLN, desa duren memiliki sumber daya air yang melimpah sampai saat ini hanya sebagian yang 
dikembangkan dan dimanfaatkan airnya. Melihat hal tersebut kami memperkenalkan energi listrik yang didapat dari sumber aliran air sungai yang ada di Desa Duren.

Indonesia merupakan negara maritim yang $2 / 3$ dari luas permukaannya ditutupi oleh air, sehingga energi air merupakan salah satu bidang yang sangat potensial untuk dikembangkan dengan kondisi seperti ini. Kondisi angin di Indonesia juga sangat bervariasi dan relatif kurang stabil di setiap tempat, sehingga turbin air lebih aplikatif dari pada turbin angin karena air di indonesia relatif stabil. Massa jenis air yang hampir 1000 kali lipat massa jenis udara menyebabkan gaya dan torsi yang mempengaruhi turbin semakin besar (Gibran, 2017).

Tenaga air merupakan salah satu energi terbarukan yang dapat dimanfaatkan untuk menggantikan pembangkit berbahan bakar fosil. Namun aliran ari tidak semuanya memiliki head yang tinggi sehingga belum termanfaatkan secara optimal. Hal ini dapat menjadi refrensi untuk memanfaatkan aliran air yang tidak memiliki head yang tinggi menjadi sebuah aliran vortex (pusaran) untuk menambah energi yang dihasilkan aliran air (Tanjung, et, I, 2019).

Aliran vortex yang juga dikenal sebagai aliran pulsating atau pusaran dapat terjadi pada berbagai macam fluida seperti pada air, minyak, udara. Contohnya suatu fluida yang mengalir di dalam pipa yang mengalami perubahan mendadak. Aliran vortex dianggap suatu kerugian dalam suatu aliran fluida meskipun sebenarnya ada yang menguntungkan. Belakangan ini prinsip aliran vortex sangat banyak digunakan sebagai pembangkit listrik mikro (F. Sumantri and M. Fitri, 2017).

Sumber energi untuk pembangkit listrik tingkat mikro ini pun melimpah tersedia dialam. Adapun contoh dari sumber energi yang dapat digunakan untuk pembangkit listrik mikro ini antara lain angin, matahari, panas bumi, dan air. Dimana, semua energi itu sangat melimpah di alam. Salah satu yang sering kita jumpai untuk pembangkit listrik ini biasanya menggunakan tenaga Air (mikrohidro). Dan untuk pembangkit listrik jenis mikrohidro ini contohnya Seperti "Gravitation Water Vortex Power Plant". Dimana pembangkit listrik tersebut menggunakan tenaga pusaran air akibat adanya gaya gravitasi untuk memutar turbin yang nantinya dapat menghasilkan sumber pasokan listrik (Fathoni, 2019) . 
Vortex ini masih menjadi produk unggulan dalam bidang energy terbarukan yang ramah lingkungan dengan efisiensi yang tinggi. Namun pada prakteknya pemanfaatan energi air masih membutuhkan saluran air yang deras, sehingga pada umumnya sumber energi air dengan saluran air yang rendah sama sekali belum termanfaatkan. Beberapa contohnya hampir semua sungai di Indonesia dengan saluran air yang rendah tapi debit yang cukup besar sama sekali belum dimanfaatkan, sementara jumlah sungai di Indonesia cukup melimpah.

Desa Duren Kecamatan Gading terletak di daerah pegunungan sebelah selatan Kabupaten Probolinggo merupakan salah satu desa pegunungan yang memiliki pasokan listrik terbatas atau belom mendapatkan pasokan listrik dari PLN. Daerah tersebut belum mendapatkan pasokan listrik dari PLN masyarakat setempat memanfaatkan saluran irigasi sebagai pembangkit listrik tenaga pusaran air (vortex), sementara daerah tersebut sangat memungkinkan untuk membuat pembagkit listrik tenaga pusaran air (vortex) karena saluran irigasi sangat layak untuk dijadikan lokasi pembuatan. Dengan adanya pembangkit listrik tenaga pusaran air (vortex) dapat meringankan masyarakat desa duren tekait kebutuhan listrik yang belum mendapatkan pasokan listrik dari PLN.

Vortex adalah jenis green technology yang termasuk dalam kategori pembangkit listrik tenaga mikrohidro. Saat ini sedang dikategorikan sebagai tenaga mikrohidro karena pembangkit listrik maksimum yang dilaporkan tidak melebihi 100kW. Keuntungan utama dari pembangkit listrik ini adalah persyaratan head air yang sangat rendah serta ramah lingkungan. Di pembangkit ini, air melewati lubang masuk (Inlet) yang besar dan lurus, yang kemudian mengalir secara tangensial ke cekungan bundar. Air kemudian akan membentuk pusaran yang kuat, yang keluar dari saluran keluar (Outlet) di bagian tengah bawah dari basin. Karena persyaratan head air yang sangat rendah, pembangkit tidak bekerja pada perbedaan tekanan tetapi pada kekuatan dinamis yang dihasilkan oleh pusaran. Oleh karena itu, biaya pengembangan dan pembangkit listrik sangat rendah di Vortex dibandingkan dengan teknologi tenaga air lainnya (Wardhana, 2019).

Wadah (basin) atau tempat penampung air yang nantinya akan terjadi pembentukan vortex ini. Tes eksperimental telah dilakukan untuk membandingkan kinerja sistem basin berbentuk kerucut dengan sistem basin silinder. Karena peningkatan nilai velocity head dengan peningkatan 
kedalaman dan kekuatan vortex yang lebih besar, efisiensi turbin lebih besar di basin berbentuk kerucut dibandingkan dengan silinder (Dhakal, 2015).

Turbin ini dinamakan sebagai Gravitation Water Vortex Power plant (GWVPP) oleh penemunya Frans Zotleterer berkebangsaan Austria, tetapi nama turbin ini dikenal juga sebagai turbin vortex atau turbin pusaran air. Sesuai dengan namanya pusaran air, turbin ini memanfaatkan pusaran air buatan untuk memutar sudu turbin dan kemudian energi pusaran air diubah menjadi energi putaran pada poros. Prosesnya air dari sungai dialirkan melalui saluran masuk ke tangki turbin yang berbentuk lingkaran dan di bagian tengah dasar tangki terdapat saluran buang berupa lingkaran kecil. Akibat saluran buang ini maka air mengalir akan membentuk aliran pusaran air. Ketinggian air (head) yang diperlukan untuk turbin ini 0,7 - $2 \mathrm{~m}$ dan debit berkisar 1000 liter per detik. Turbin ini sederhana, mudah dalam perawatannya, kecil, kuat, dan bertahan hingga 50 - 100 tahun (Zotloterer, 2002).

Irigasi adalah Energi air yang dapat dimanfaatkan sebagai energi listrik dengan memanfaatkan tenaga potensial yang tersedia (potensi air terjun dan kecepatan aliran saluran irigasi) berdasarkan bluprint pengelolaan energi nasional tahun (2005) (Kementrian Energi Dan Sumber Daya Mineral, 2009) .

Irigasi didefinisikan sebagai suatu cara pemberian air, baik secara alamiah ataupun buatan kepada tanah dengan tujuan untuk memberi kelembapan yang berguna bagi pertumbuhan tanaman.

Secara alamiah:

a. secara alamiah air disuplai kepada tanaman melalui air hujan.

b. cara alamiah lainnya, adalah melalui genangan air akibat banjir dari sungai, yang akan menggenangi suatu daerah selama musim hujan, sehingga tanah yang ada dapat siap ditanami pada musim kemarau.

Secara buatan:

Ketika penggunaan air ini mengikutkan pekerjaan rekayasa teknik dalamskala yang cukup besar, maka hal tersebut disebut irigasi buatan (Artificial Irrigation).

Irigasi buatan secara umum dapat dibagi dalam 2 (dua) bagian, yaitu :

a. Irigasi Pompa (Lift Irrigation), dimana air diangkat dari sumber air yang rendah ke tempat yang lebih tinggi, baik secara mekanis maupun manual. b. Irigasi Aliran (Flow Irrigation), dimana air dialirkan ke lahan pertanian 
secara gravitasi dari sumber pengambilan air.

\section{Metode}

Metode pengabdian yang digunakan adalah mendesain ulang pembangkit listrik tenaga pusaran air (Vortex) yang memanfaatkan saluran irigasi, sekaligus memberikan penyuluhan kepada penanggung jawab sarana tersebut guna keberlangsungannya. Kegiatan dilakukan terhadap pemilik pembangkit listrik tenaga pusaran air (Vortex) di desa Duren. Kegiatan diawali dengan melakukan survei lokasi unntuk mengetahui masalah pada pembangkit listrik teanga pusaran air (Vortex) di desa Duren tersebut. Gambar 1. Kemudian dilanjutkan dengan mendesain ulang pembangkit listrik tenaga pusaran air (Vortex) yang memanfatkan saluran irigasi. Pelaksaan kegiatan pengabdian ini melibatkan mahasiswa yang melaksanakan program Kuliah Kerja Nyata (KKN) di daerah tersebut, dan pemilik pembangkit listrik tenaga pusaran air (Vortex).

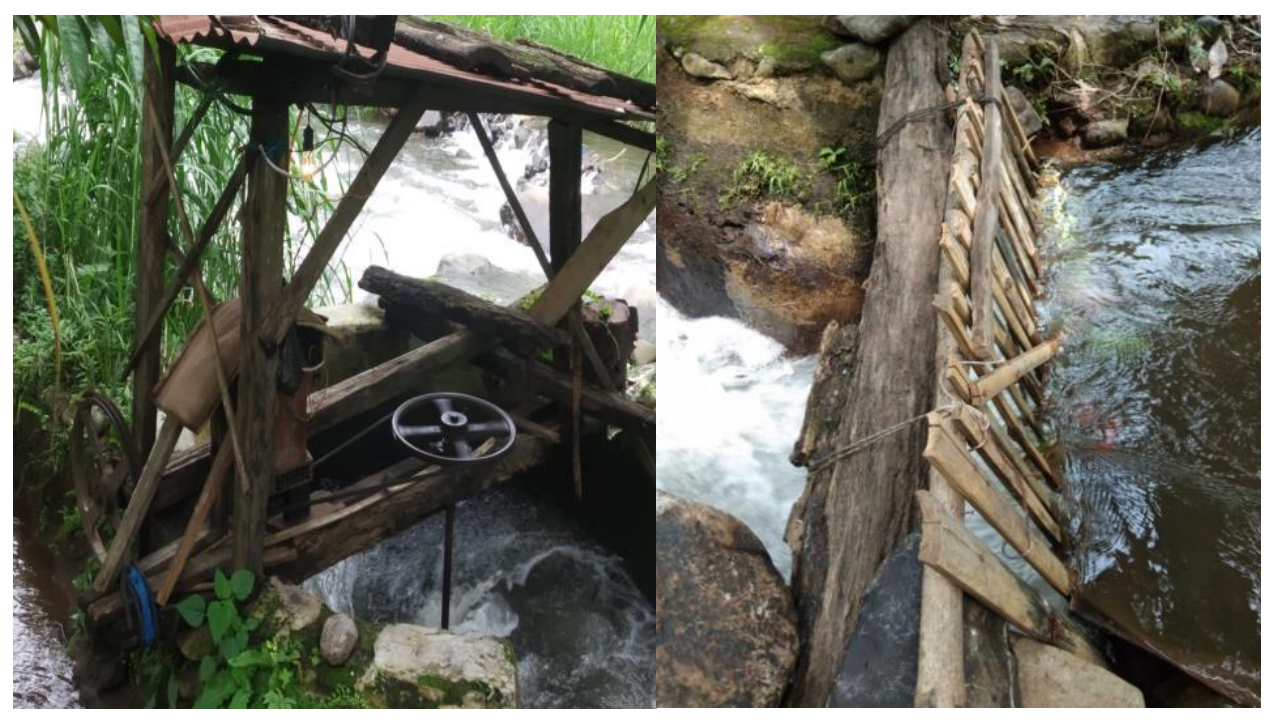

\section{A. Pembangkit Listrik Tenaga Vortex $\quad$ B. Saluran Bendungan Irigasi}

Gambar 1. (A), (B) Kondisi Vortex Desa Duren

\section{a. Penyuluhan}

Metode penyuluhan ini dilakukan dengan maksud untuk memberikan gambaran Redesign yang akan dikerjakan oleh Mahasiswa yang Kuliah Kerja Nyata (KKN) di lokasi tersebut. Kegiatan ini dilakukan di tempat pemilik Vortex tersebut. Melalui 
metode ini diharapkan pemilik Vortex tersebut dapat memahami dan membantu proses Redesaign dan pemasangan hingga pengoperasian yang benar.

\section{b. Re-desaign Vortex}

Metode kegiatan ini yaitu perbaikan dan pemasangan adalah dimaksudkan untuk memperbaiki semua komponen yang sudah tidak berfungsi hingga siap untuk digunakan. Untuk komponen pembangkit yang tidak bisa diperbaiki maka dilakukan pemasangan baru. Sebelum dilakukan perbaikan maka terlebih dahulu dilakukan pengukuran fungsinya. Kegiatan ini berlangsung hingga Listrik dihasilkan oleh pembangkit. Kemudian diawali dengan memperbaiki penyangga sekaligus atap dari Vortex tersebut, dilanjutkan dengan pengecekan generator dan mengganti as roda dari penyangga turbin Vortex. Setelah itu, memperbaiki saluran irigasi.

Pada kegiatan pertama telah berhasil dipasang berapa unit di suatu tempat. Untuk mengetahui keberhasilan kegiatan ini dilakukan monitor di kemudian hari dan kelihatan peralatan masih berfungsi dengan baik. Maka dari itu dilanjutkan pemasangan tahap kedua dengan memastikan bahwa peralatan terpasang bisa berjalan sesuai fungsinya.

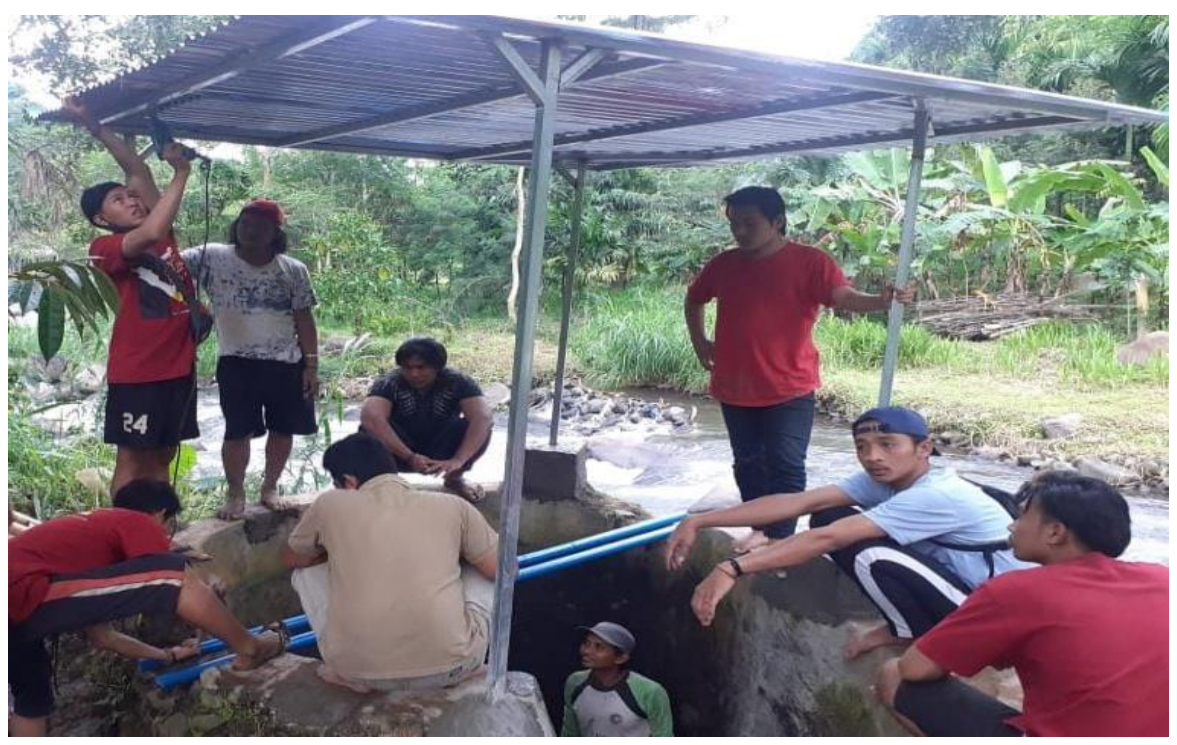

Gambar 2. Pemasangan Atap Vortex 


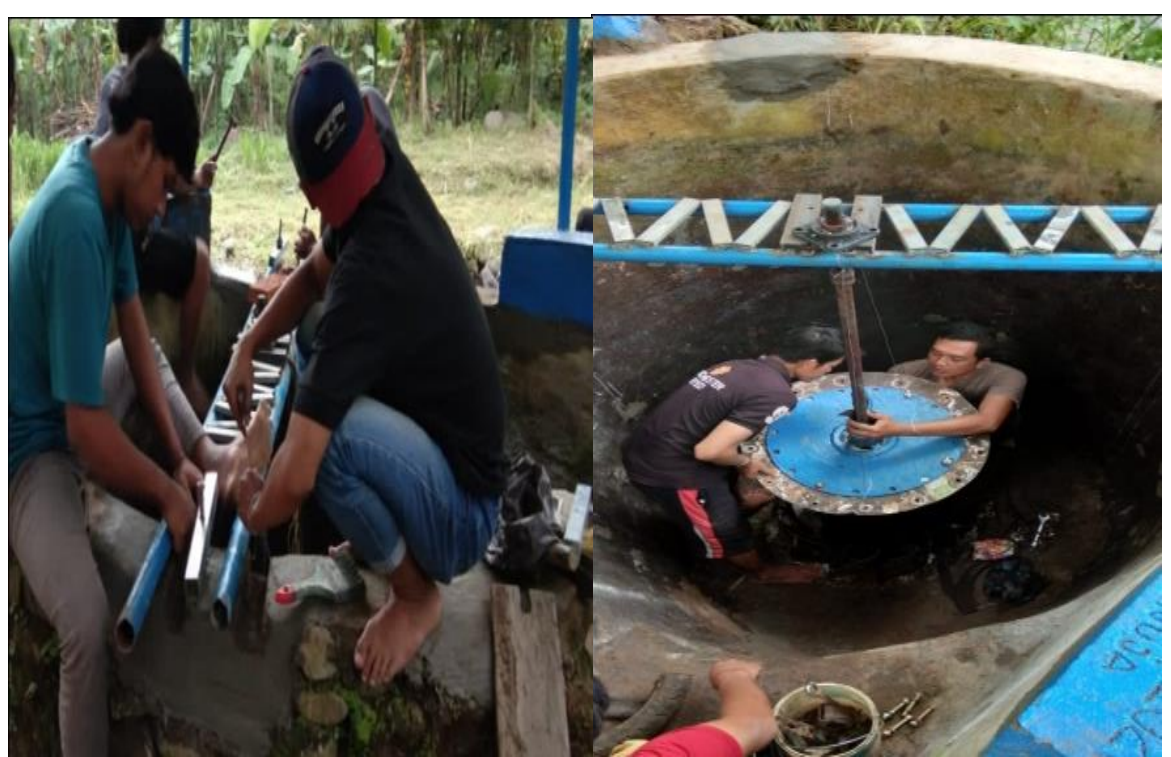

Gambar 3. Pemasangan As penyangga turbin Vortex dan Turbin Vortex

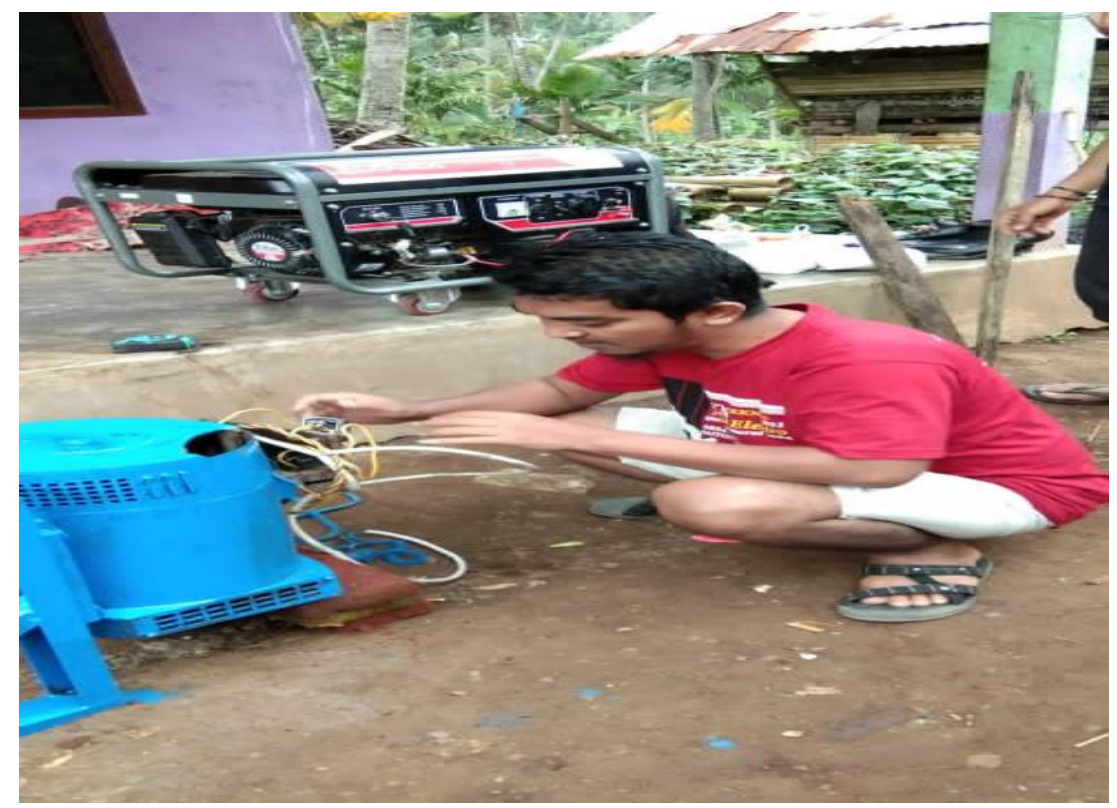

Gambar 4. Pengecekan Generator 


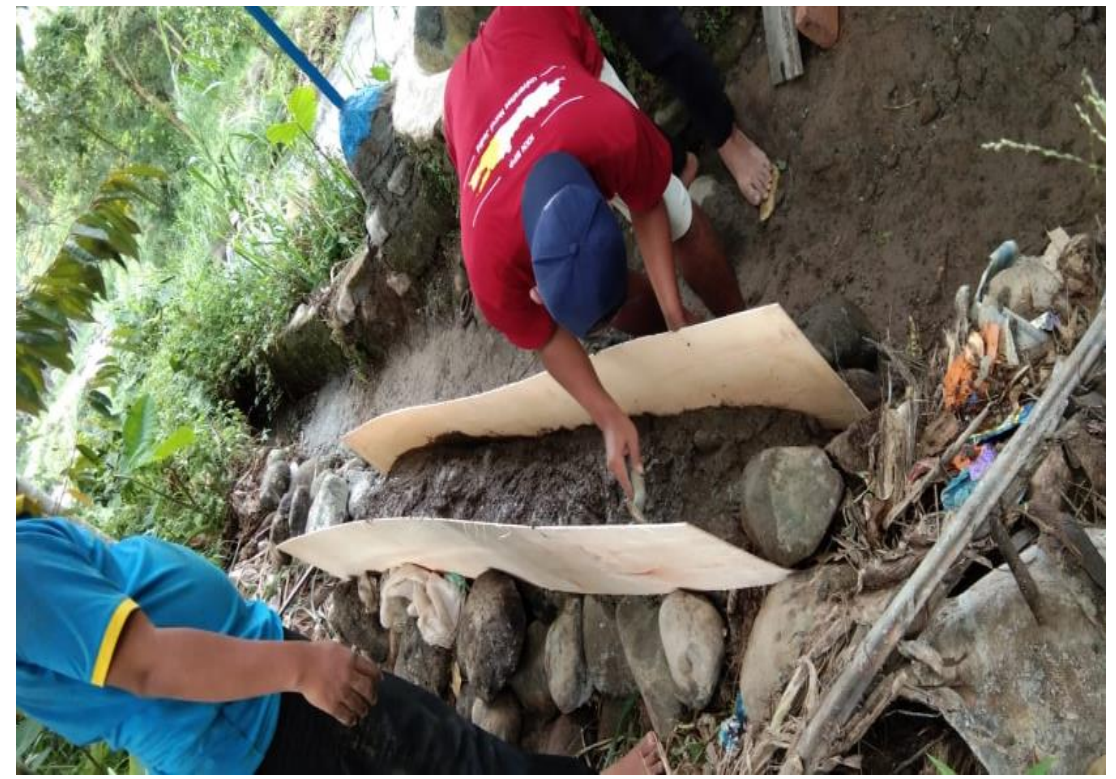

Gambar 5. Perbaikan Saluran Irigasi

\section{Hasil}

Hasil yang diperoleh dari Pengabdian masyarakat pemanfatan saluran irigasi sebagai pembagkit listri tenaga pusaran air (Vortex) di desa Duren menghasilkan daya listrik yang mampu menghidupkan 5 rumah dengan beban sebagaimana berikut:

Tebel 1. Hasil Pengujian pada Rumah 1

\begin{tabular}{ccc}
\hline No & Beban & Daya Listrik \\
\hline 1 & (5) Lampu & 25 watt \\
\hline 2 & (1) Tv & 75 watt \\
\hline 3 & (1) Setrika & 100 watt \\
\hline 4 & (1) kipas & 15 watt \\
\hline & Jumlah & 215 watt \\
\hline
\end{tabular}

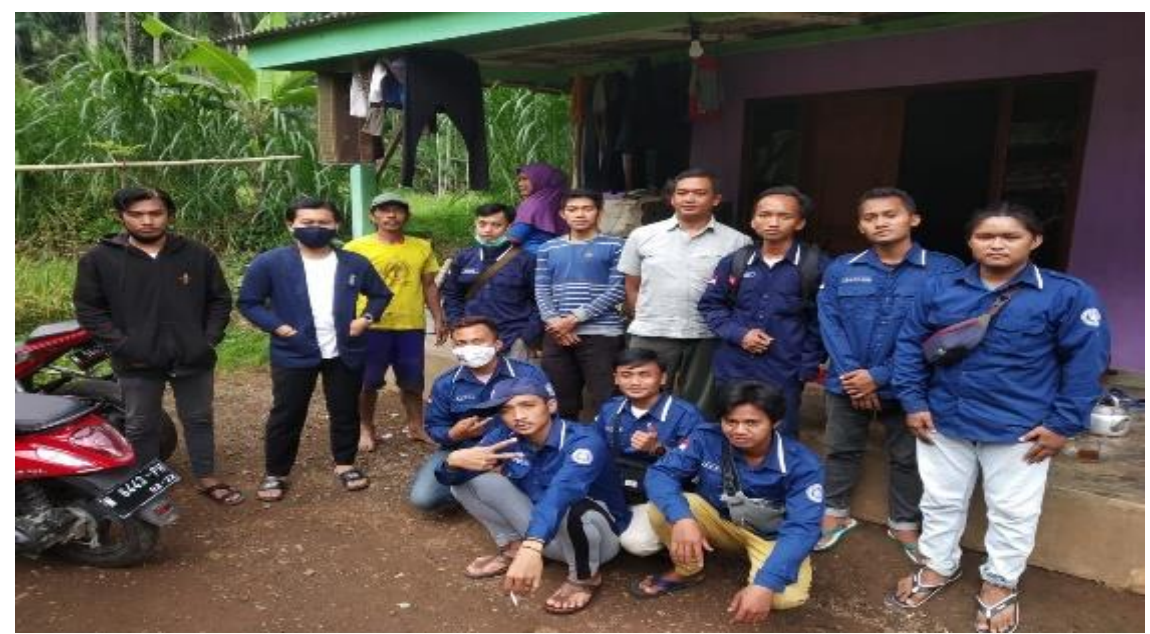


Tebel 2. Hasil Pengujian pada Rumah 2

\begin{tabular}{ccc}
\hline No & Beban & Daya Listrik \\
\hline 1 & (5) Lampu & 25 watt \\
\hline 2 & (1) Tv & 75 watt \\
\hline & Jumlah & 100 watt \\
\hline
\end{tabular}

Tebel 3. Hasil Pengujian pada Rumah 3

\begin{tabular}{ccc}
\hline No & Beban & Daya Listrik \\
\hline 1 & (5) Lampu & 25 watt \\
\hline
\end{tabular}

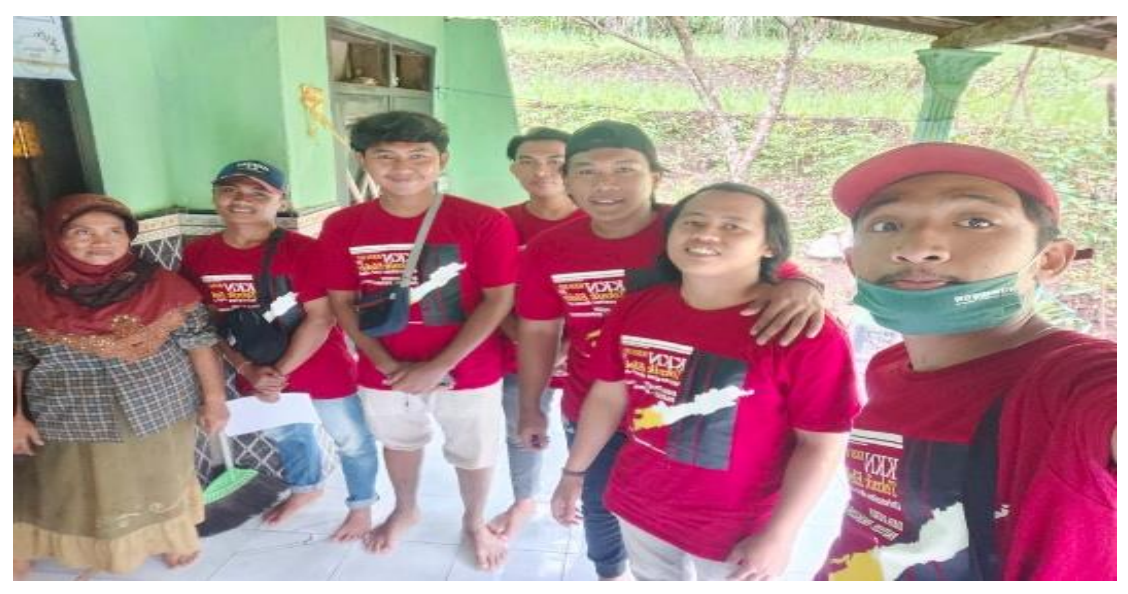

Gambar 7. Hasil Pengujian pada Rumah 2 dan 3

Tabel 4. Hasil Pengujian pada Rumah 4

\begin{tabular}{ccc}
\hline No & Beban & Daya Listrik \\
\hline 1 & (16) Lampu & 80 watt \\
\hline 2 & (1) Tv & 75 watt \\
\hline 3 & (1) setrika & 100 watt \\
\hline & Jumlah & 255 watt \\
\hline
\end{tabular}




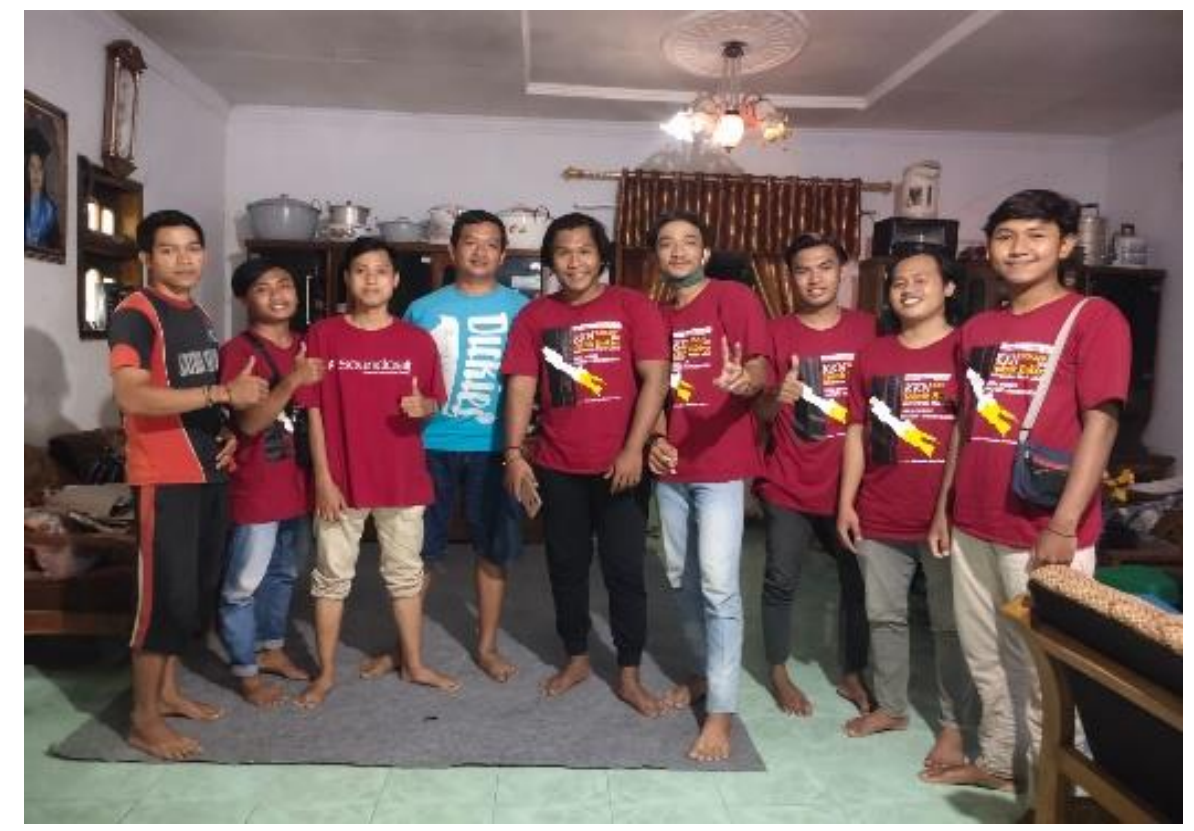

Gambar 8. Hasil Pengujian pada Rumah 4

Tebel 5. Hasil Pengujian pada Rumah 5

\begin{tabular}{ccc}
\hline No & Beban & Daya Listrik \\
\hline 1 & (13) Lampu & 65 watt \\
\hline 2 & (1) Tv & 75 watt \\
\hline 3 & (1) Kipas & 15 watt \\
\hline 4 & (1) setrika & 100 watt \\
\hline & Jumlah & 255 watt \\
\hline
\end{tabular}

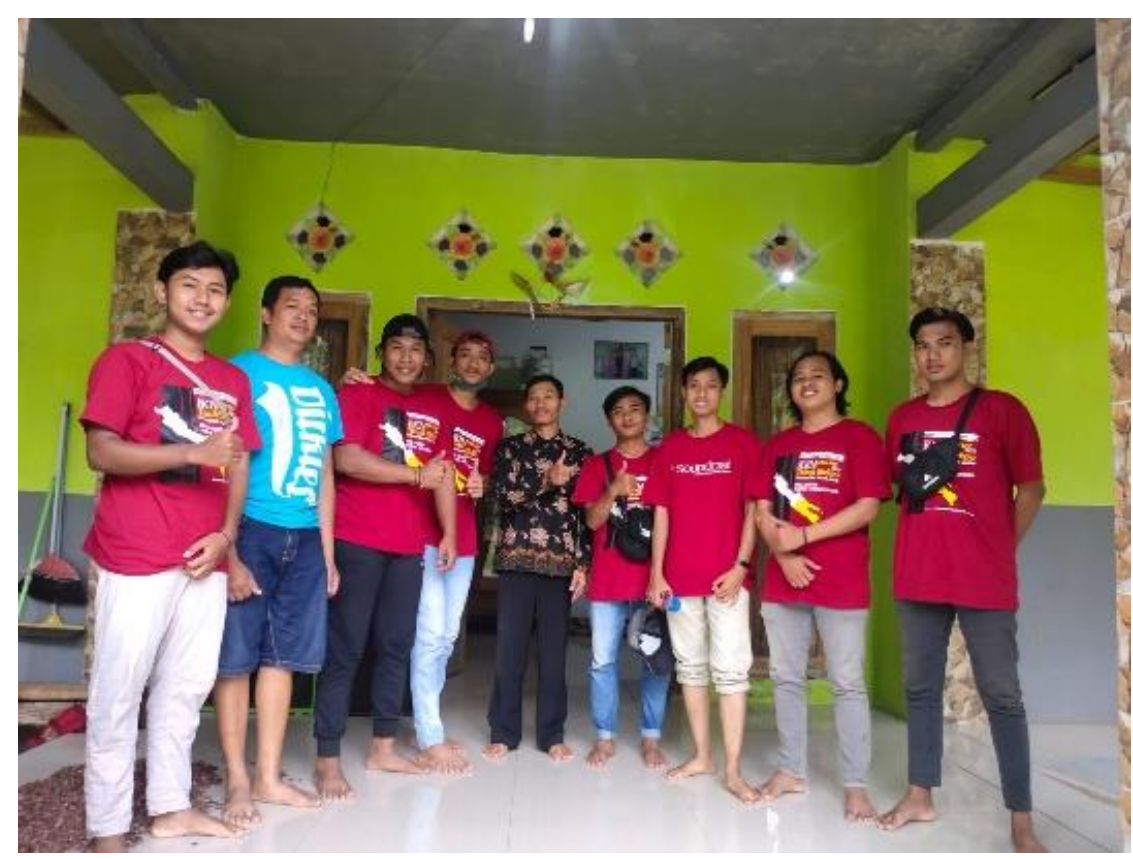


Gambar 9. Hasil Pengujian pada Rumah 5

\section{Pembahasan}

Hasil yang diperoleh dari kegiatan pemanfaatan saluran irigasi pembangkit listrik tenaga pusaran air (Vortex) di desa Duren adalah:

a. Peningkatan pengetahuan masyarakat tentang Vortex

Sebelum melakukan pemasangan peralatan terlebih dahulu mengadakan pertemuan dengan tokoh masyarakat di desa Duren untuk menentukan tempat atau sarana penting yang akan dipasang peralatan. Pada lokasi pemasangan dan penjelasan tentang Vortex terhadap warga penanggung jawab. Pengarahan juga diberikan secara langsung kepada pihak yang diberi tugas untuk mengoperasikan peralatan tersebut sehari-hari pada saat pemasangan. Dari kegiatan ini diketahui bahwa masyarakat belum mengetahui bagaimana merawat dan menjaga fasilitas Pembangkit listrik tenaga pusaran air yang benar. Materi yang disampaikan adalah tentang prinsip dasar Vortex dan dilanjutkan dengan tata cara instalasi dan perawatan.

Pada kegiatan pertama telah berhasil di pasang berapa unit di suatu tempat. Untuk mengetahui keberhasilan kegiatan ini di lakukan monitor di kemudian hari dan keliatan peralatan masih tetap berfungsi dengan baik. Maka dari itu pemasangan tahap kedua memastikan bahwa semua peralatan terpasang dan bisa berjalan sesuai fungsinya.

b. Fungsi pembangkit listrik tenaga pusaran air untuk kebutuhan masyarakat Desa Duren.

Dengan telah di pasangnya pembangkit listrik tenaga pusaran air telah menjadi solusi terbaik untuk membantu masyarakat mendapatkan aliran listrik. Kemudian pengujian pembangkit listrik tenaga pusaran air di Desa Duren membuktikan bahwa masyarakat desa duren dapat memanfaatkan energi listrik pusaran air untuk memenuhi kebutuhan mereka di rumah.

Kegiatan yang di laksanakan bersama mahasiswa kuliah kerja nyata dan masyarakat bisa memberikan dampak positif pada semua pihak. Di pihak masyarakat dapat menambah ilmu pengetahuannya di bidang teknologi tepat guna untuk mengatasi krisis listrik. Terselip harapan bagi masyarakat bahwa 
di Desa Duren akan mencapai perbaikan dari segi ekonomi setelah kebutuhan energy terpenuhi.

\section{Kesimpulan}

Dari kegiatan pengabdian ini dapat dibuat kesimpulan:

a. Memanfaatkan saluran irigrasi sebagai Pembangkit listrik tenaga pusaran air (Vortex) untuk menghasilkan daya listrik sebagai kebutuhan masyarakat di desa Duren yang belum mendapatkan pasokan Listrik PLN.

b. Meredisaign Pembangkit listrik tenaga pusaran air (Vortex) menjadi lebih baik dan me maximalkan Tegangan arus listrik pada alat tersebut.

c. Membantu memecahkan masalah yang terkendala pada pembangkit.

d. Meminimalisir kotoran sampah yang menghambat pada aliran arus pembangkit.

e. Merenovasi tempat pembangkit menjadi lebih bagus

\section{Referensi}

Nafi, Moh, Imam., M. Hasan Basri., Hilman Iskawanto I., Bachtera Indarto., Alfi Tranggono A S. 2020. "Rancang bangun gravitation water Vortex power plant (GWVPP) Berbasis basin silinder", JEECAE vol.5, No.1, Mei 2020.

Gibran, S. Gultom, Z. Lubis, and P. G. Sembiring. 2017. "Rancang Bangun Turbin Vortex Dengan Casing Berpenampang Lingkaran Yang Menggunakan Sudu Diameter $46 \mathrm{Cm}$ Pada 3 Variasi Jarak Antara Sudu Dan Saluran Keluar," J. Din., vol. 5, no. 2.

Tanjung, I. F. et al. 2019. "Analisa Performansi Turbin Vortex Menggunakan Perangkat Lunak Cfd Dengan Variasi Dimensi Sudu I Dan Sudu lii, Debit Air Masuk Serta Luas Saluran Buang," J. Din., vol. 3, no. 4.

Sumantri, F. and M. Fitri,. 2017. "Perancangan alat uji vortex bebas dan vortex paksa," vol. 8, no. 2.

Fathoni, H. D., M. S. Drs. Bachtera Indarto, and M. S. Iim Fatimah, S.Si. 2019. PENGARUH PERBEDAAN VARIASI JUMLAH BLADE TURBIN PADA PEMBANGKIT LISTRIK TENAGA PUSARAN GRAVITASI AIR (GWVPP) BERBASIS BASIN KERUCUT. Surabaya: Departemen Fisika Fakultas Sains Institut Teknologi Sepuluh Nopember. 
Wardhana, E. M., A. Santoso, and A. R. Ramdani, "Analysis of Gottingen 428 Airfoil Turbine Propeller Design with Computational Fluid Dynamics Method on Gravitational Water Vortex Power Plant," Int. J. Mar. Eng. Innov. Res., vol. 3, no. 3, 2019.

Dhakal, S., A. B. Timilsina, R. Dhakal, D. Fuyal, and T. R. Bajracharya. 2015. "Comparison of cylindrical and conical basins with optimum position of runner: Gravitational water vortex power plant \$," vol. 48.

Zotloterer, F. 2002. "Zotloterer Gravitational Vortex Plant,".

Kementrian Energi Dan Sumber Daya Mineral. 2009. Master Plan Pembangunan Ketenaga Listrikan. Jakarta 